\title{
Who's in the Dark: Satellite Based Estimates of Electrification Rates
}

Submitted October 22, 2009 as a book chapter in "Urban Remote Sensing: Monitoring, Synthesis and Modeling in the Urban Environment” Xiaojun Yang (editor), WileyBlackwell, Chichester, UK. To be published in 2010.

Christopher D. Elvidge, Earth Observation Group, NOAA National Geophysical Data Center, 325 Broadway, Boulder, Colorado 80303, USA (chris.elvidge@noaa.gov)

Kimberly E. Baugh, Cooperative Institute for Research in Environmental Sciences, University of Colorado, Boulder, Colorado USA.

Paul C. Sutton, Department of Geography, University of Denver, Denver, Colorado USA.

Budhendra Bhaduri, Oak Ridge National Laboratory, Oak Ridge, Tennessee, USA.

Benjamin T. Tuttle, Department of Geography, University of Denver, Denver, Colorado USA.

Tilotamma Ghosh, Cooperative Institute for Research in Environmental Sciences, University of Colorado, Boulder, Colorado USA.

Daniel Ziskin, Cooperative Institute for Research in Environmental Sciences, University of Colorado, Boulder, Colorado USA.

Edward H. Erwin, NOAA National Geophysical Data Center, 325 Broadway, Boulder, Colorado 80303, USA 


\section{Abstract}

A technique has been developed to estimate the percent population having electric power access based on the presence of satellite detected nighttime lighting. A global survey was conducted for the year 2006 using nighttime lights collected by the U.S. Air Force Defense Meteorological Satellite Program (DMSP) in combination with the U.S. Department of Energy Landscan population dataset. The survey includes results for 229 countries and more than 2000 subnational units. The results are compared to reported electrification rates for 87 countries compiled from a variety of sources by the International Energy Agency. The DMSP derived estimate of number of people worldwide who lack access to electricity is 1.62 billion, only slightly larger than the 1.58 billion estimated by the International Energy Agency.

Keywords: Electrification rates, nighttime lights, population grid.

\section{Introduction}

The wide distribution of $6+$ billion people across more than 200 countries has made it difficult to collect and synthesize consistent data on the human condition at anything more that broad national and sub-national units. The primary reporting is for population and economic variables such as Gross Domestic Product (GDP). There is a paucity of data on quality-of-life variables and where such data are collected variations in the methods, survey questions used and timetables make the reports difficult to assimilate into a global assessment. Satellite sensors 
provide one of the few globally consistent and repeatable sources of observations. Clearly it would be useful to have one or more satellite derived indices that could used to estimate socioeconomic parameters, such as the distribution of economic activity, population, and living conditions. Historically, earth observing systems that aim for global coverage have been designed to observe environment and weather, not human activities. It would be sheer luck to find data from one of these global earth observing systems that also made a direct observation of a human activity. But there are several examples that can be pointed to. Satellite sensors such as NOAA's AVHRR and NASA's MODIS detect fires, many of which are anthropogenic in origin, using a combination of thermal bands. These same sensors detect urban heat islands and paucity of green vegetation in heavily built up urban cores. But the most remarkable example of a global earth observing satellite sensor detection of human activity are the nighttime lights collected by the U.S. Air Force Defense Meteorological Satellite Program (DMSP) Operational Linescan System (OLS).

Human beings around the world use lights at night to enable the extension of activity past sundown. The brightness of lights is affected by multiple factors, such as population density, economic activity, infrastructure investment, lighting type, lighting fixtures, and even cultural preferences in lighting. Despite these complexities, a number of studies have used nighttime lights to map phenomena which would be cost prohibitive to map based on ground surveys. This includes the distribution of economic activity (Doll et al. 2000, Ebener et al. 2005, Ghosh et al. 2009), the density of constructed surfaces (Elvidge et al. 2007a), poverty levels (Elvidge et al. 2009a), and resource consumption (Sutton et al. 2009).

By overlaying lights and population (Figure 1) it is possible to observe clear differences in the quantity of lighting per person around the world. Populations in the developed world 
generally have a surplus of lighting, yielding the blue-green and white areas on Figure 1. Areas with high population count and modest lighting levels show up as pink. (in portions of India and China). The red colors on Figure 1 indicate populations where no lighting was detected by the DMSP sensor.

In this study we develop a new application for the nightime lights, the estimation of electrification rates. For year 2005 the International Energy Agency (IEA) World Energy Outlook (IEA 2006) estimated the global electrification rate at $75.6 \%$ with 1.58 billion people living without electricity. Lack of electric power is a poverty indicator with links to conditions that are detrimental to health and well being such as lack of refrigeration for food, poor water quality, lack of sanitary facilities, and limited access to health care services. We map the spatial extent of electrification in 2006 based on the presence of DMSP detected lighting. Combining the spatial extent of lighting with population count we estimate electrification rates. We compare the DMSP estimates of electrification rates with reported rates for 87 countries published for year 2005 by the International Energy Agency (IEA 2006). Finally we discuss possible sources of error and ideas for improvements.

\section{Insert Figure 1 about here.}

\section{Methods}

\section{Data Sources}

The two primary data sources for this study are DMSP nighttime lights and gridded population count. Both the nighttime lights and population grid were from year 2006. National level reference data on the extent of electrification were drawn from the International Energy Agency's World Energy Outlook (WEO) 2006. 
The DMSP-OLS visible band was designed to enable the detection of moonlit clouds at night in the visible band. A photomultiplier tube is used to intensify the visible band signal by about a million fold. This enables the detection of moonlit clouds and lighting present at the Earth’s surface. NGDC has developed a capability to make cloud-free composites of the nighttime visible band OLS data (Elvidge et al. 2001). Additional procedures are used to remove ephemeral lights (mostly fires) and background noise to produce gridded stable lights products.

There are several gridded population products available. We have found the U.S. Department of Energy Landscan data (Dobson et al. 2001 and Bhaduri et al. 2002) to be the most compatible with the DMSP nightime lights. Both are produced in a geographic projection with the same 30 arc second grid resolution. Also, the recent Landscan products have not used nighttime lights as an input, thus there is not circularity in using the two data sets. The Landscan data are spatial allocations of census reported population numbers based on models developed using three satellite derived data sources: 1) NASA MODIS land cover, 2) the topographic data from the Shuttle Radar Topography Mission (SRTM), and 3) high resolution outlines of human settlements derived from the Controlled Image Base (CIB) from the U.S. National Geospatial Intelligence Agency (NGA). Landscan data are referred to as population count instead of population density, which is based on residence. On a population density grid commercial centers and airports have very low numbers, despite the fact that there are substantial numbers of people present during certain hours. Landscan attempts to represent the spatial distribution of population based on person hours. Thus population is distributed across residential, commercial, industrial and public areas such as airports and schools.

The IEA has been compiling and reporting on electrification rates since 2002 in a 
publication series titled "World Energy Outlook”. They admit there is no internationally accepted definition for electric power access and no standard method for collecting such data. Their objective has been to report the percentage of the population has access to electricity in their home. Data are collected from various sources, ranging from government agencies, international development programs and energy research organizations. Where the country reported data appeared contradictory, out of date, or unreliable the IEA reports estimates based on consideration of data from similar countries, earlier surveys, data from the international organizations, and journal articles.

\section{Data Processing}

While the fires and background noise were removed in the production of the stable lights for 2006 - the gas flares are still present. To avoid overestimating electrification rates in countries with substantial numbers of gas flares, areas lit by gas flares were masked out and not used in the analysis. The locations of gas flares in the DMSP nighttime lights had already been determined in consultation with high resolution imagery available in Google Earth (Elvidge et al., 2009b). The remaining lights are all deemed to be from electric lighting. A binary mask was generated for the areas lit by the presence of gas flares. The gas flare mask was applied to the Landscan grid to zero out the population count in areas lit by gas flares. A second mask was produced for the remaining lights. This mask was used to divide the gas flare free population grid into two segments A) population with lighting detected (Figure 3), and B) population with no lighting detected (Figure 4). The percent electrification rate is then calculated as:

Population with DMSP lighting (A)

Total Population $(\mathrm{A}+\mathrm{B})$

X 100.

The analysis was conducted at both a national and subnational level. 


\section{Insert Figure 2 about here. \\ Insert Figure 3 about here. \\ Insert Figure 4 about here.}

\section{Results}

Using the data shown in Figures 2-4 we estimated the electrification rates for 229 countries - listed in descending population order in Table 1. The national level DMSP estimates are represented in map form in Figure 5. The total number of people found to be without electricity is 1.62 billion, only $2.5 \%$ larger than the 1.58 billion estimated by the IEA. The IEA estimates are listed in the third data column in Table 1 and are shown in map form in Figure 6. Because the Landscan data are disaggregated it is possible to estimate electrification rates at the subnational level (Figure 7) or at user defined spatial aggregations.

Insert Figure 5 about here.

Insert Figure 6 about here.

Insert Figure 7 about here.

Insert Figure 8 about here.

\section{Discussion}

Figure 8 compares the DMSP estimated and IEA reported electrification rates. Overall, there is general agreement between the DMSP and IEA electrification rate estimates. Developed countries with near 100\% electrification rates yielded DMSP electrification rates ranging from 98 to 100\% (Table 2). The countries having DMSP estimated electrification rates less than 20\% (Table 3) are countries long recognized among the poorest on Earth. 
However, it is possible to identify cases where the two estimates differ substantially. Table 4 lists the top ten countries where the IEA reported electrification rate is higher than the DMSP estimate. Leading here are Thailand, China and Cuba, each with more than a twenty percent difference between the two numbers. Countries having ten to twenty percent higher electrification rates reported by the IEA include Brazil, Philippines, Paraguay, Mongolia, Chile, Cameroon and Algeria. We do not know the source of the discrepancies.

The IEA estimates China has a 99.4\% electrification rate, citing the Chinese Ministry of Science and Technology and the U.S. Department of Energy National Renewable Energy Laboratory. In contrast, the DMSP estimated electrification rate is $75.6 \%$. Thus, the DMSP estimate identified 320 million more people without electricity in China than the IEA had reported. That is more than the entire population of the USA! A large portion of the Chinese population identified to be without electricity are in Sichuan Province and surrounding provinces in the interior south-central China, known to be amongst the poorest regions of China. It is possible that the IEA reported electrification rate for China is valid in the wealthy coastal areas and underestimates the lack of electric power access in less wealthy the interior regions. Or it may be that the definition being used to define "access to electricity" is so broad that it encompasses $99.4 \%$ of the Chinese population. Another possibility is that the electrification rate is indeed high, but use of outdoor lighting is so sparse in some regions that the DMSP sensor is unable to detect the lighting. Similar possibilities exist for the other countries listed on Table 4.

Table 5 lists the top eleven countries where the DMSP estimates exceed the IEA reported electrification rates. Leading the list is Iraq, for which the IEA estimated an electrification rate of 15\% and the DMSP estimate was 88.1\%. In WEO 2004 (IEA, 2004) the electrification rate for Iraq was reported as 94.5\%.for the year 2002. The number was revised down for 2005 based 
on a Iraq government report (COSIT, 2005), which includes results of a household survey regarding the stability of electric power service in the months following the U.S. invasion in 2003. The IEA summarized the COSIT surveys, concluding that only 15\% of Iraqi households had reliable access to electricity. The disparity between the two electrification rate estimates for Iraq can be attributed to the DMSP's ability to detect intermittent lighting over the course of a year.

Other countries where the DMSP estimated electrification rate exceeded the IEA reported value include Congo, Pakistan, Sri Lanka, Qatar, Indonesia, Lesotho, Bangladesh, Afghanistan, Gabon, and India. The Indian estimate from DMSP is 75.5\% nearly matches the DMSP estimate for China (75.6\%). As with China, the core of the DMSP identified population with no lighting detected are located in a heavily populated zone known as the poorest region of the nation, in this case the Ganges River Plain stretching from Delhi to Calcutta.

There are several possible sources of error in the DMSP estimates. There may be errors of omission, or undercounting of the population with access to electricity in rural areas where the outdoor lighting is not bright enough for DMSP detection. This is the major source of error in developed countries such as the USA, France and New Zealand, which are believed to have near 100\% electrification but fall 1-2\% short of this in the DMSP estimates (Table 2). This style of error may be larger in the developing countries that have lower electric power consumption levels, such as China and India. There may errors of commission, or overcounting of the population with access to electricity in areas that have street lighting and commercial lighting, yet no electric power access in a portion of the homes in the same pixel. Another source of discrepancy arises from homes with intermittent or sporadic electric power service. In the case of Iraq the IEA only tallied population with reliable electric power service in the estimation of 
the electrification rate. The DMSP data were processed to detect intermittent lighting, yielding a substantially higher estimate of the electrification rate. Finally, it should be noted that the DMSP electrification rate estimates were derived from areas that are devoid of lighting from gas flares. That is to say, in areas with onshore gas flares, the electrification rate has been estimated outside of the area lit by the gas flares. This includes portions of countries listed by Elvidge et al. (2009 b), including Russia, Nigeria, Iran, Iraq, Algeria, Libya and others.

\section{Insert Figure 8 about here.}

\section{Conclusion}

We derived the first systematic global assessment of electrification rates by combining DMSP nighttime lights with a population density grid. In this analysis, the electrification rate was estimated by tallying the population count in areas having DMSP lighting as compared to the total population. Using this technique we have a standardized product, with reporting for 229 countries and more than 2000 sub-national units. In contrast, the only other available reporting on international electrification rates comes from the International Energy Agency (IEA), which in 2006 reported electrification rates for 87 countries.

There are several potential areas for improvement in the estimation of electrification rates based on nighttime lights. The current method is flawed since it overestimates the population without access to electricity in sparsely populated rural areas in developed countries that have electricity, but do not produce enough light to be detected by the DMSP satellite. Conversely, the method over estimates the electrification rate in urban areas in developing countries where DMSP lighting detected from streetlights and other outdoor lighting types in areas where 
households have no electric power access or unreliable access. It may be possible to identify areas having intermittent access to electricity based on the percent frequency of light detection in the DMSP annual cloud-free composites. To address the problem with gas flares obscuring lights from small towns and villages the best solution would be to collect the nighttime lights data at higher spatial resolution (Elvidge et al. 2007b).

One of the applications for the full resolution grid of the population count in areas without DMSP detected lighting is to identify areas of the world that could benefit from installation of sustainable solar and wind energy systems. In many of these areas, people are burning kerosene to produce subsistence levels of heat and lighting that cannot be detected by DMSP. Mills et al (2007) have shown that liquid fuels are extremely inefficient and costly light sources. The only thing cheap about this approach to lighting is the cost of the lanterns. Given the emphasis being placed on reducing carbon emissions, Mills et al. (2007) have developed low cost photovoltaic panels and light emitting diode (LED) fixtures that enable families to produce light using locally generated electricity without the expense of extending the electric power grid. This approach has similarity to the rapid expansion of cell phone usage in places where the land line telephone system is antiquated and decrepit.

While there are some known sources of error in the current product, the method does provide electrification rates using a standardized definition and standardized data sources, with complete global coverage. We anticipate that there will be improvements to the nighttime lights approach to estimating electrification rates. We also anticipate that nighttime lights will be useful for detecting changes in electric power access. This could include both expansions and contractions in access to electric power. 


\section{References}

Bhaduri, B., E. Bright, P. Coleman, and J. Dobson. 2002. LandScan: Locating people is what matters. Geoinformatics 5, pp. 34-37.

COSIT, 2004. Iraq Living Conditions Survey 2004, Volume III: Socio-economic Atlas of Iraq, Central Organization for Statistics and Information Technology, Ministry of Planning and Development Cooperation, Baghdad, Iraq.

Dobson, J., E.A. Bright, P.R. Coleman, R.C. Durfee and B.A. Worley. 2000. LandScan: a global population database for estimating populations at risk. Photogrammetric Engineering and Remote Sensing 66, pp. 849-857.

Doll, C.N.H., Muller, J.-P. and Elvidge, C.D. 2000. Night-time imagery as a tool for global mapping of socio-economic parameters and greenhouse gas emissions. Ambio 29, pp. 157-162.

Ebener, S., C. Murray, A. Tandon and C,. Elvidge. 2005. From wealth to health: modeling the distribution of income per capita at the sub-national level using nighttime lights imagery. International Journal of Health Geographics 4, pp. 5-11.

Elvidge, C.D., M.L. Imhoff, K.E. Baugh, V.R. Hobson, I. Nelson, J. Safran, J.B. Dietz, B.T. Tuttle. 2001. Night-time lights of the world: 1994-1995. ISPRS Journal of Photogrammetry \& Remote Sensing 56, pp. 81-99. 
Elvidge, C.D., Tuttle, B.T., Sutton,, P.C., Baugh, K.E., Howard, A.T., Milesi, C., Bhaduri, B., Nemani R., 2007a, Global distribution and density of constructed impervious surfaces. Sensors, 7, pp. 1962-1979.

Elvidge, C.D., Cinzano, P., Pettit, D.R., Arvesen, J., Sutton, P., Small, C., Nemani, R., Longcore, T., Rich, C., Safran, J., Weeks, J., Ebener, S., 2007b. The Nightsat mission concept, International Journal of Remote Sensing 28(12), pp. 2645 - 2670.

Elvidge, C. D., P. C. Sutton, T. Ghosh, B. T. Tuttle, K. E. Baugh, B. Bhaduri, and E. Bright, 2009a. A Global Poverty Map Derived from Satellite Data, Computers and Geosciences 35, pp. $1652-1660$.

Elvidge, C. D., Ziskin, D., Baugh, K. E., Tuttle, B. T., Ghosh, T., Pack, D. W., Erwin, E. H., Zhizhin, M., 2009b. A Fifteen Year Record of Global Natural Gas Flaring Derived from Satellite Data, Energies, 2 (3), pp. 595-622.

Ghosh, T., Anderson, S., Powell, R. L., Sutton, P. C., Elvidge, C. D., 2009. Estimation of Mexico’s Informal Economy and Remittances Using Nighttime Imagery, Remote Sensing, 1 (3), pp. 418-444.

International Energy Agency, 2004. World Energy Outlook, Appendix to Chapter 10: Electrification Tables. 
International Energy Agency, 2006. World Energy Outlook, Appendix B Electricity Access.

Mills, E., 2005. The Specter of Fuel-Based Lighting. Science, 308(5726), pp. 1263-1264.

Sutton,P.C., Anderson, S.J., Elvidge, C.D., Tuttle, B.T., Ghosh, T., 2009. Paving the planet: impervious surface as proxy measure of the human ecological footprint. Progress in Physical Geography 33(4), pp. 510-527. 
.List of Tables

\begin{tabular}{|c|c|c|c|}
\hline \multicolumn{4}{|c|}{ Estimates of National Electrification Rates For 2006} \\
\hline China & $1,308,905,728$ & 76.8 & 99.4 \\
\hline India & $1,104,764,800$ & 75.7 & 55.5 \\
\hline United States & $291,958,400$ & 99.0 & \\
\hline Indonesia & $223,445,600$ & 78.9 & 54 \\
\hline Brazil & $181,723,136$ & 79.9 & \\
\hline Pakistan & $165,333,376$ & 91.4 & 54 \\
\hline Bangladesh & $146,274,784$ & 55.0 & 32 \\
\hline Russia & $137,334,752$ & 86.1 & \\
\hline Nigeria & $131,131,568$ & 40.7 & 46 \\
\hline Japan & $121,929,464$ & 99.5 & \\
\hline Mexico & $106,107,432$ & 93.7 & \\
\hline Philippines & $84,165,344$ & 64.9 & 80.5 \\
\hline Vietnam & $82,873,472$ & 80.6 & 84.2 \\
\hline Germany & $82,284,928$ & 98.8 & \\
\hline Egypt & $78,002,176$ & 99.9 & 98 \\
\hline Ethiopia & $74,580,856$ & 12.6 & 15 \\
\hline Turkey & $68,341,640$ & 83.1 & \\
\hline Iran & $64,260,172$ & 94.5 & 97.3 \\
\hline Thailand & $64,074,048$ & 72.3 & 99 \\
\hline Congo, DRC & $62,137,408$ & 23.5 & 5.8 \\
\hline France & $59,562,360$ & 98.0 & \\
\hline United Kingdom & $59,185,168$ & 99.1 & \\
\hline Italy & $56,513,852$ & 99.4 & \\
\hline South Korea & $46,776,532$ & 100.0 & \\
\hline Ukraine & $46,517,576$ & 85.0 & \\
\hline Myanmar & $46,174,136$ & 27.1 & 11.3 \\
\hline South Africa & $45,957,312$ & 74.0 & 70 \\
\hline Colombia & $43,065,580$ & 82.7 & 86.1 \\
\hline Sudan & $41,005,056$ & 33.5 & 30 \\
\hline Argentina & $39,522,200$ & 87.9 & 95.4 \\
\hline Spain & $39,451,484$ & 97.3 & \\
\hline Poland & $38,388,900$ & 96.9 & \\
\hline Tanzania & $37,158,680$ & 17.9 & 11 \\
\hline Kenya & $35,813,744$ & 29.3 & 14 \\
\hline Canada & $32,498,608$ & 97.3 & \\
\hline Algeria & $32,268,142$ & 88.0 & 98.1 \\
\hline
\end{tabular}




\begin{tabular}{|c|}
\hline $\begin{array}{l}\text { Morocco } \\
\text { Afohanistan }\end{array}$ \\
\hline Uganda \\
\hline Nepal \\
\hline Peru \\
\hline Uzbekistan \\
\hline Iraq \\
\hline Saudi Arabia \\
\hline Venezuela \\
\hline Malaysia \\
\hline North Korea \\
\hline Ghana \\
\hline Romania \\
\hline Yemen \\
\hline Mozambique \\
\hline Sri Lanka \\
\hline Australia \\
\hline Madagascar \\
\hline Syria \\
\hline Cameroon \\
\hline Cote d'Ivory \\
\hline Netherlands \\
\hline Chile \\
\hline Kazakhstan \\
\hline Burkina Faso \\
\hline Cambodia \\
\hline Malawi \\
\hline Ecuador \\
\hline Niger \\
\hline Guatemala \\
\hline Zimbabwe \\
\hline Senegal \\
\hline Angola \\
\hline Mali \\
\hline Zambia \\
\hline Cuba \\
\hline Serbia \& Montenegro \\
\hline Belgium \\
\hline Portugal \\
\hline Czech Republic \\
\hline Greece \\
\hline Chad \\
\hline Hungary \\
\hline
\end{tabular}

$32,187,260$

77.5

85.1

$31,032,188$

29.6

7

29,390,972

15.4

8.9

$28,748,452$

32.7

33

$28,113,022$

72.3

$27,253,948$

69.0

94.4

$26,810,654$

88.1

$26,496,632$

98.8

96.7

$24,973,556$

93.2

98.6

$23,057,040$

90.4

97.8

$22,510,660$

37.6

22

$22,411,932$

49.2

$22,266,808$

46.5

88.4

$21,162,504$

55.4

36.2

$20,290,134$

22.0

6.3

$20,229,058$

66

$19,666,616$

95.4

92.1

$18,730,568$

14.8

15

$18,670,416$

95.1

90

$17,516,510$

36.4

47

$17,016,192$

50

$16,320,233$

53.7

100.0

$15,528,649$

87.3

98.6

$15,366,266$

72.7

$13,915,535$

15.5

$13,900,239$

20.1

$13,240,124$

15.6

18.6

82.1

7
90.3

$13,057,767$

90.3

$12,536,623$

19.8

$12,447,853$

78.6

$12,220,747$

78.1

34.1

34

$12,128,555$

22

$11,902,221$

48.3

15

$11,707,643$

29.9

22.6

$11,336,282$

34.9

19

$11,227,785$

74.9

95.8

$10,787,706$

90.4

$10,431,084$

100.0

$10,328,523$

98.3

$10,250,290$

99.6

$10,137,542$

97.2

18.5

94.2 


\begin{tabular}{|c|c|c|c|}
\hline Belarus & $9,762,124$ & 78.3 & \\
\hline Tunisia & $9,752,671$ & 91.6 & 98.9 \\
\hline Rwanda & $9,629,262$ & 13.6 & \\
\hline Guinea & $9,362,449$ & 21.0 & \\
\hline Dominican Republic & $9,090,900$ & 90.7 & 92.5 \\
\hline Bolivia & $8,985,352$ & 66.0 & 64.4 \\
\hline Somalia & $8,729,994$ & 24.7 & \\
\hline Sweden & $8,441,214$ & 98.0 & \\
\hline Burundi & $8,245,397$ & 7.7 & \\
\hline Austria & $8,171,036$ & 98.8 & \\
\hline Azerbaijan & $8,046,536$ & 82.1 & \\
\hline Benin & $7,919,077$ & 37.7 & 22 \\
\hline Haiti & $7,808,419$ & 29.3 & 36 \\
\hline Switzerland & $7,629,250$ & 99.6 & \\
\hline Bulgaria & $7,319,524$ & 92.1 & \\
\hline Honduras & $7,182,415$ & 72.6 & 61.9 \\
\hline Tajikistan & $6,941,439$ & 87.4 & \\
\hline El Salvador & $6,778,252$ & 93.6 & 79.5 \\
\hline Paraguay & $6,507,533$ & 70.5 & 85.8 \\
\hline Laos & $6,389,236$ & 22.0 & \\
\hline Israel & $6,151,147$ & 99.9 & 96.6 \\
\hline Sierra Leone & $5,921,899$ & 25.0 & \\
\hline Jordan & $5,893,604$ & 97.5 & 99.9 \\
\hline Libya & $5,827,906$ & 96.5 & 97 \\
\hline Nicaragua & $5,527,336$ & 60.6 & 69.3 \\
\hline Togo & $5,522,532$ & 33.3 & 17 \\
\hline Slovakia & $5,459,714$ & 95.1 & \\
\hline Papua New Guinea & $5,210,907$ & 17.6 & \\
\hline Denmark & $5,157,683$ & 96.6 & \\
\hline Kyrgyzstan & $5,099,656$ & 86.6 & \\
\hline Turkmenistan & $5,090,828$ & 85.9 & \\
\hline Finland & $5,089,830$ & 95.2 & \\
\hline Eritrea & $4,723,351$ & 27.0 & 20.2 \\
\hline Georgia & $4,559,424$ & 74.9 & \\
\hline Bosnia \& Herzegovina & $4,476,640$ & 84.1 & \\
\hline Central African Republic & $4,300,050$ & 25.2 & \\
\hline Croatia & $4,299,097$ & 95.0 & \\
\hline Singapore & $4,206,270$ & 100.0 & 100 \\
\hline Moldova & $4,176,313$ & 85.5 & \\
\hline Norway & $4,098,739$ & 88.3 & \\
\hline Costa Rica & $4,067,027$ & 92.9 & \\
\hline Ireland & $3,937,104$ & 97.0 & \\
\hline Puerto Rico & $3,824,000$ & 100.0 & \\
\hline
\end{tabular}




\begin{tabular}{l} 
New Zealand \\
Congo \\
Lithuania \\
Albania \\
Lebanon \\
Uruguay \\
Mauritania \\
Panama \\
Armenia \\
Oman \\
Liberia \\
Mongolia \\
Jamaica \\
West Bank \\
United Arab Emirates \\
Bhutan \\
Latvia \\
Macedonia \\
Kuwait \\
Namibia \\
Slovenia \\
Lesotho \\
Botswana \\
The Gambia \\
Guinea-Bissau \\
Gabon \\
Gaza Strip \\
Estonia \\
Mauritius \\
Swaziland \\
Timor Leste \\
Trinidad \& Tobago \\
Qatar \\
Fiji \\
Reunion \\
Cyprus \\
Guyana \\
Comoromininue \\
\hline
\end{tabular}

$3,801,472$

87.1

$3,752,949$

60.5

19.5

$3,603,037$

78.5

$3,471,578$

76.2

$3,458,243$

99.6

99.9

$3,424,161$

90.1

95.4

$3,197,154$

36.2

$3,134,964$

80.1

85.2

$2,985,608$

87.9

95.9

95.5

$2,923,682$

30.0

$2,826,511$

52.4

2,631,911

99.8

87.3

$2,517,877$

100.0

99.6

91.9

$2,327,470$

33.7

$2,204,224$

75.8

$2,059,063$

91.9

2,011,370

99.4

100

$1,984,458$

43.0

$1,984,024$

95.8

$1,974,952$

34.3

$1,640,102$

38.5

$1,599,751$

53.8

45.0

$1,407,918$

29.4

$1,358,236$

68.5

47.9

$1,305,448$

100.0

$1,277,632$

85.8

$1,219,407$

100.0

93.6

$1,123,708$

49.1

$1,027,709$

9.5

99.7

99.1

96.1

70.5

786,719

56.1

754,849

99.8

753,955

99.5

719,444

69.0

600,507

33.3

581,127

100.0

99

483,098

100.0

461,789

84.4

435,168

18.1

426,392

100.0 


\begin{tabular}{|c|c|c|c|}
\hline Guadeloupe & 381,306 & 100.0 & \\
\hline Cape Verde & 376,338 & 81.8 & \\
\hline Malta & 368,860 & 100.0 & \\
\hline Western Sahara & 331,567 & 92.1 & \\
\hline Brunei & 303,062 & 96.9 & 99.2 \\
\hline Solomon Is. & 293,641 & 0.5 & \\
\hline Belize & 286,146 & 78.6 & \\
\hline The Bahamas & 271,502 & 94.2 & \\
\hline Barbados & 261,993 & 100.0 & \\
\hline Iceland & 243,255 & 88.3 & \\
\hline Djibouti & 203,931 & 59.4 & \\
\hline New Caledonia & 199,394 & 67.6 & \\
\hline French Polynesia & 182,166 & 96.6 & \\
\hline Sao Tome \& Principe & 179,070 & 61.7 & \\
\hline Netherlands Antilles & 177,571 & 99.7 & 99.6 \\
\hline Mayotte & 170,490 & 99.7 & \\
\hline St. Lucia & 164,331 & 100.0 & \\
\hline Guam & 158,857 & 100.0 & \\
\hline French Guiana & 155,574 & 79.9 & \\
\hline Vanuatu & 148,457 & 15.6 & \\
\hline Samoa & 139,479 & 49.6 & \\
\hline Virgin Is. & 98,686 & 100.0 & \\
\hline St. Vincent \& Grenadines & 92,502 & 99.3 & \\
\hline Jersey & 88,366 & 100.0 & \\
\hline Grenada & 75,259 & 100.0 & \\
\hline Northern Mariana Is. & 73,153 & 99.9 & \\
\hline Aruba & 71,740 & 100.0 & \\
\hline Andorra & 71,447 & 98.8 & \\
\hline Isle of Man & 68,639 & 97.9 & \\
\hline Seychelles & 68,493 & 100.0 & \\
\hline Antigua \& Barbuda & 64,016 & 99.8 & \\
\hline Tonga & 57,901 & 85.5 & \\
\hline Dominica & 57,503 & 90.8 & \\
\hline Guernsey & 56,408 & 100.0 & \\
\hline American Samoa & 50,729 & 100.0 & \\
\hline Faroe Is. & 37,755 & 73.7 & \\
\hline Monaco & 37,046 & 100.0 & \\
\hline Micronesia & 35,739 & 86.4 & \\
\hline Liechtenstein & 34,768 & 100.0 & \\
\hline Greenland & 33,363 & 76.1 & \\
\hline St. Kitts \& Nevis & 28,666 & 100.0 & \\
\hline San Marino & 25,918 & 100.0 & \\
\hline Cayman Is. & 25,902 & 100.0 & \\
\hline
\end{tabular}




British Virgin Is.
Wallis \& Futuna
Anguilla
Palau
Nauru
Cook Is.
Bermuda
Turks \& Caicos Is.
Montserrat
St. Pierre \& Miquelon
St. Helena
Falkland Is.
Kiribati
Gibraltar
Niue
Tuvalu
Norfolk I.
Maldives
Christmas I.
Vatican City
Cocos Is.

19,578

100.0

13,886

11.9

13,201

100.0

13,076

77.7

12,283

100.0

11,093

90.9

9,391

7,822

100.0

93.1

73.8

64.6

6,793

98.9

6,006

69.0

2,974

76.7

2,462

2.6

2,195

100.0

2,069

61.5

1,378

1.4

1,170

95.6

405

53.6

359

100.0

283

100.0

233

72.5 
Table 2

Countries Where Electrification Rates Are Expected To Be Near 100\%

Country $\quad$ DMSP Estimated (\%)

$\begin{array}{lr}\text { Singapore } & 100.0 \\ \text { Netherlands } & 100.0 \\ \text { Belgium } & 100.0 \\ \text { South Korea } & 100.0 \\ \text { Switzerland } & 99.6 \\ \text { Czech Republic } & 99.6 \\ \text { United Arab Emirates } & 99.6 \\ \text { Japan } & 99.5 \\ \text { Italy } & 99.4 \\ \text { United Kingdom } & 99.1 \\ \text { United States } & 99.0 \\ \text { Austria } & 98.8 \\ \text { Germany } & 98.8 \\ \text { Saudi Arabia } & 98.8 \\ \text { Portugal } & 98.3 \\ \text { Sweden } & 98.0 \\ \text { France } & 98.0\end{array}$


Table 3

Countries With Populations Over A Million And

DMSP Estimated Electrification Rates Under 20\%

$\begin{array}{lrc}\text { Country } & \text { DMSP Estimated (\%) } & \text { IEA Reported \% } \\ \text { Niger } & 19.8 & \\ \text { Malawi } & 18.6 & 7 \\ \text { Chad } & 18.5 & \\ \text { Tanzania } & 17.9 & 11 \\ \text { Papua New Guinea } & 17.6 & \\ \text { Cambodia } & 15.6 & 7 \\ \text { Burkina Faso } & 15.5 & 8.9 \\ \text { Uganda } & 15.4 & 15 \\ \text { Madagascar } & 14.8 & 15 \\ \text { Rwanda } & 13.6 & \\ \text { Ethiopia } & 12.6 & \\ \text { Timor Leste } & 9.5 & \\ \text { Burundi } & 7.7 & \end{array}$


Table 4

Top Ten Countries Where the DMSP Estimated Electrification Rate Is Lower Than The IEA Reported Rate

\begin{tabular}{llcc} 
Country & \multicolumn{2}{l}{ DMSP Estimated (\%) IEA Reported (\%) } & Difference \\
& & & \\
Thailand & 72.3 & 99.0 & -26.7 \\
China & 75.6 & 99.4 & -23.8 \\
Cuba & 74.9 & 95.8 & -20.9 \\
Brazil & 78.4 & 96.5 & -18.1 \\
Philippines & 64.9 & 80.5 & -15.6 \\
Paraguay & 70.5 & 85.8 & -15.3 \\
Mongolia & 52.4 & 64.6 & -12.2 \\
Chile & 87.3 & 98.6 & -11.3 \\
Cameroon & 36.1 & 47.0 & -10.9 \\
Algeria & 88.1 & 98.1 & -10.0
\end{tabular}


Table 5

Top Eleven Countries Where the DMSP Estimated Electrification Rate Is Higher Than The IEA Reported Rate

$\begin{array}{lccc}\text { Country } & \text { DMSP Estimated (\%) IEA Reported (\%) } & \text { Difference } \\ \text { Iraq } & 88.1 & 15.0 & 73.1 \\ \text { Congo } & 60.5 & 19.5 & 41.0 \\ \text { Pakistan } & 91.2 & 54.0 & 37.2 \\ \text { Sri Lanka } & 95.4 & 66.0 & 29.4 \\ \text { Qatar } & 96.1 & 70.5 & 25.6 \\ \text { Indonesia } & 78.8 & 54.0 & 24.8 \\ \text { Lesotho } & 34.3 & 11.0 & 23.3 \\ \text { Bangladesh } & 55.0 & 32.0 & 23.0 \\ \text { Afghanistan } & 29.6 & 7.0 & 22.6 \\ \text { Gabon } & 68.5 & 47.9 & 20.6 \\ \text { India } & 75.5 & 55.5 & 20.0\end{array}$




\section{List of Figures}

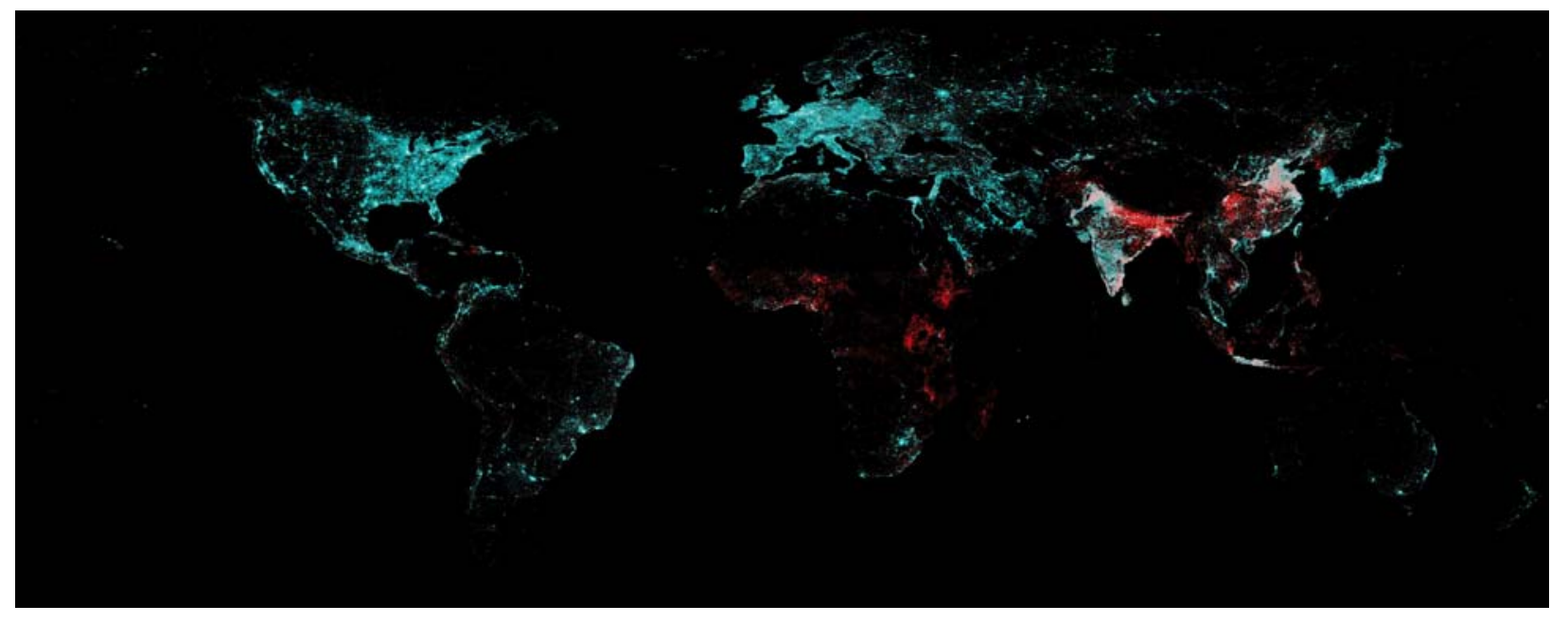

Figure 1.

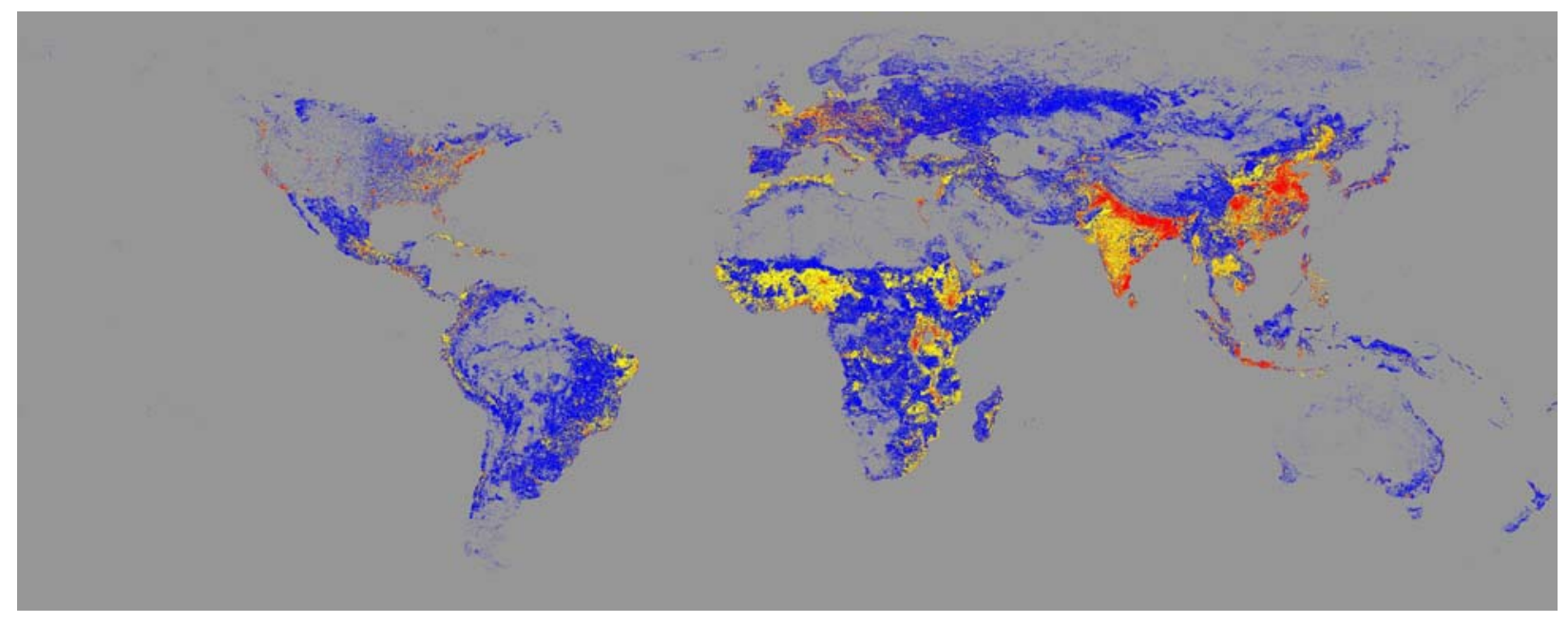

Figure 2. Landscan population count. Uninhabited areas with population counts of zero are gray. Rural areas having population counts ranging from 1-10 are blue. Suburban and densely populated rural areas with population counts ranging from 11 to 99 are yellow. Red areas have population counts of 100 or more per grid cell. 


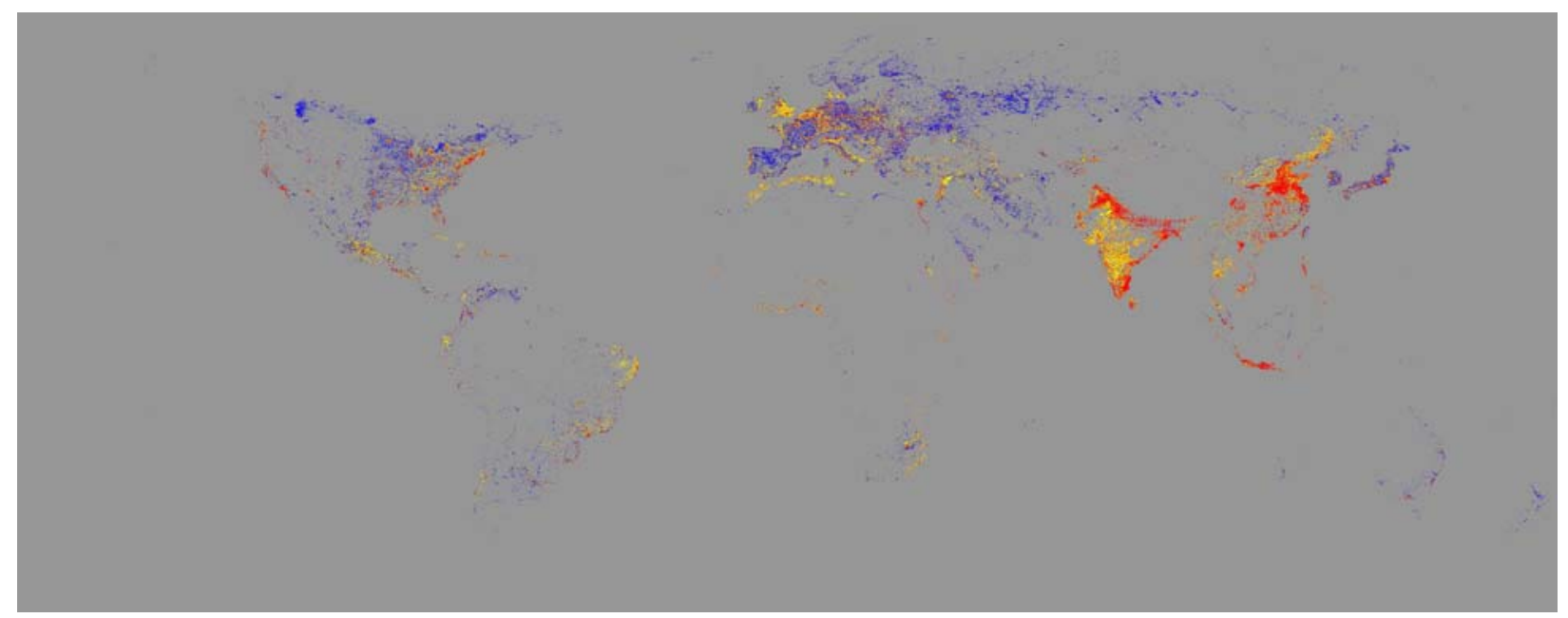

Figure 3. Landscan population count in areas with DMSP detected lighting. The color coding is the same as Figure 2.

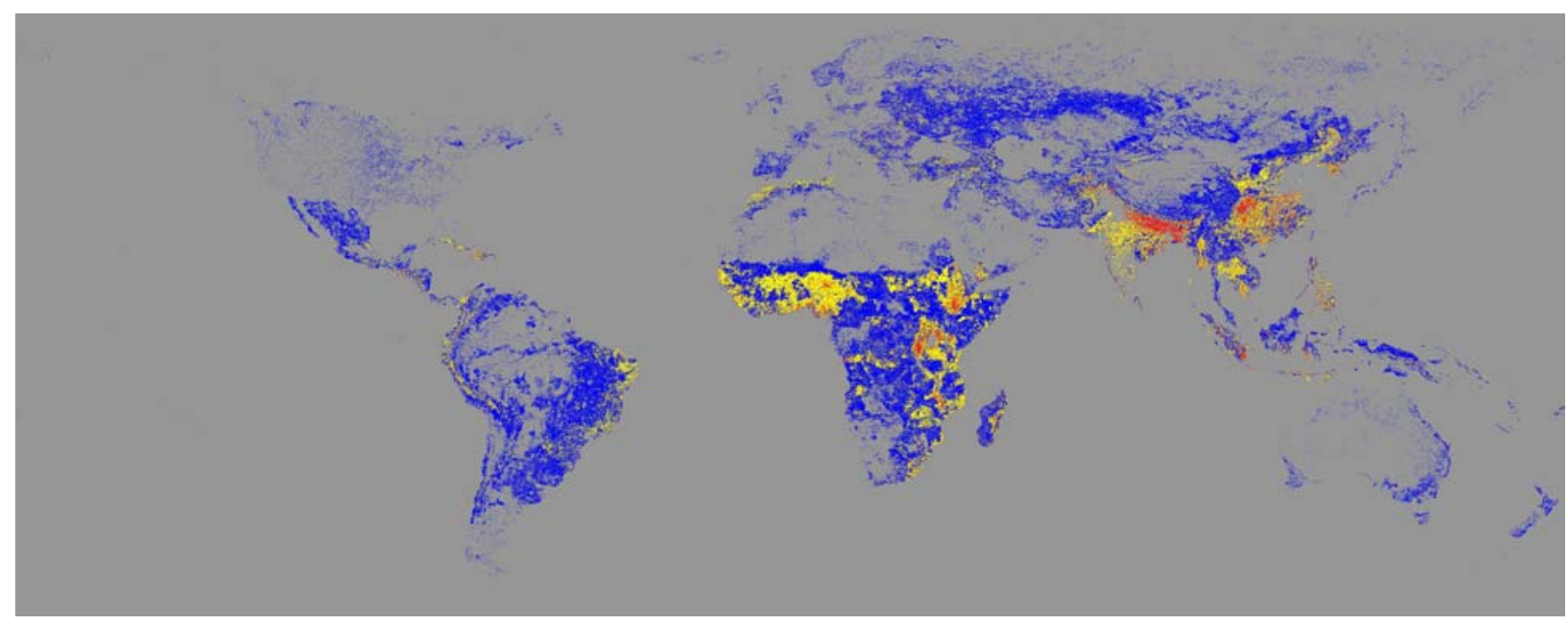

Figure 4. Landscan population count in areas with no DMSP detected lighting. The color coding is the same as Figure 2. 


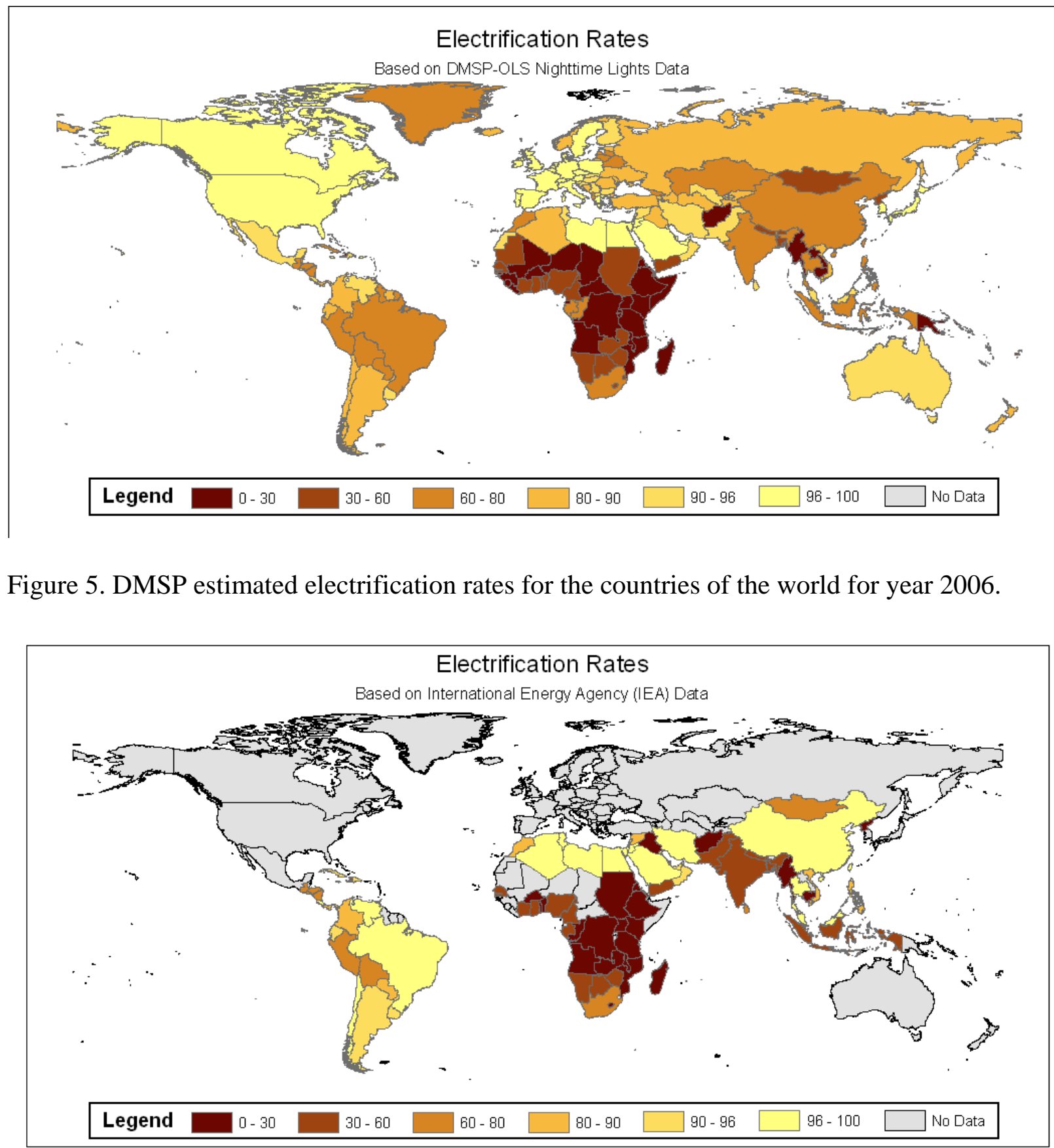

Figure 6. Electrification rates published by the IEA for year 2005. 


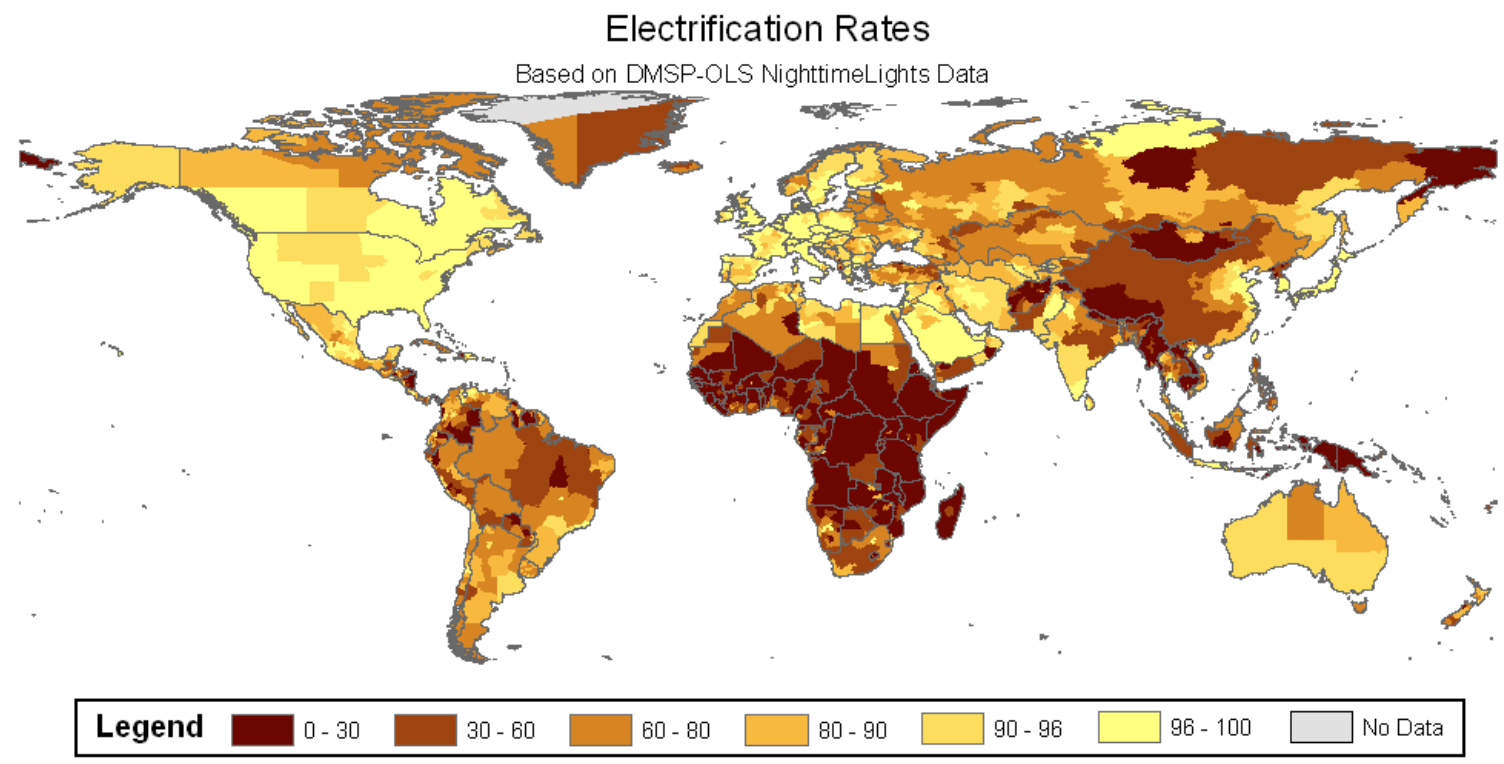

Figure 7. DMSP estimated electrification rates for primary subnational units (states and provinces) for year 2006. 


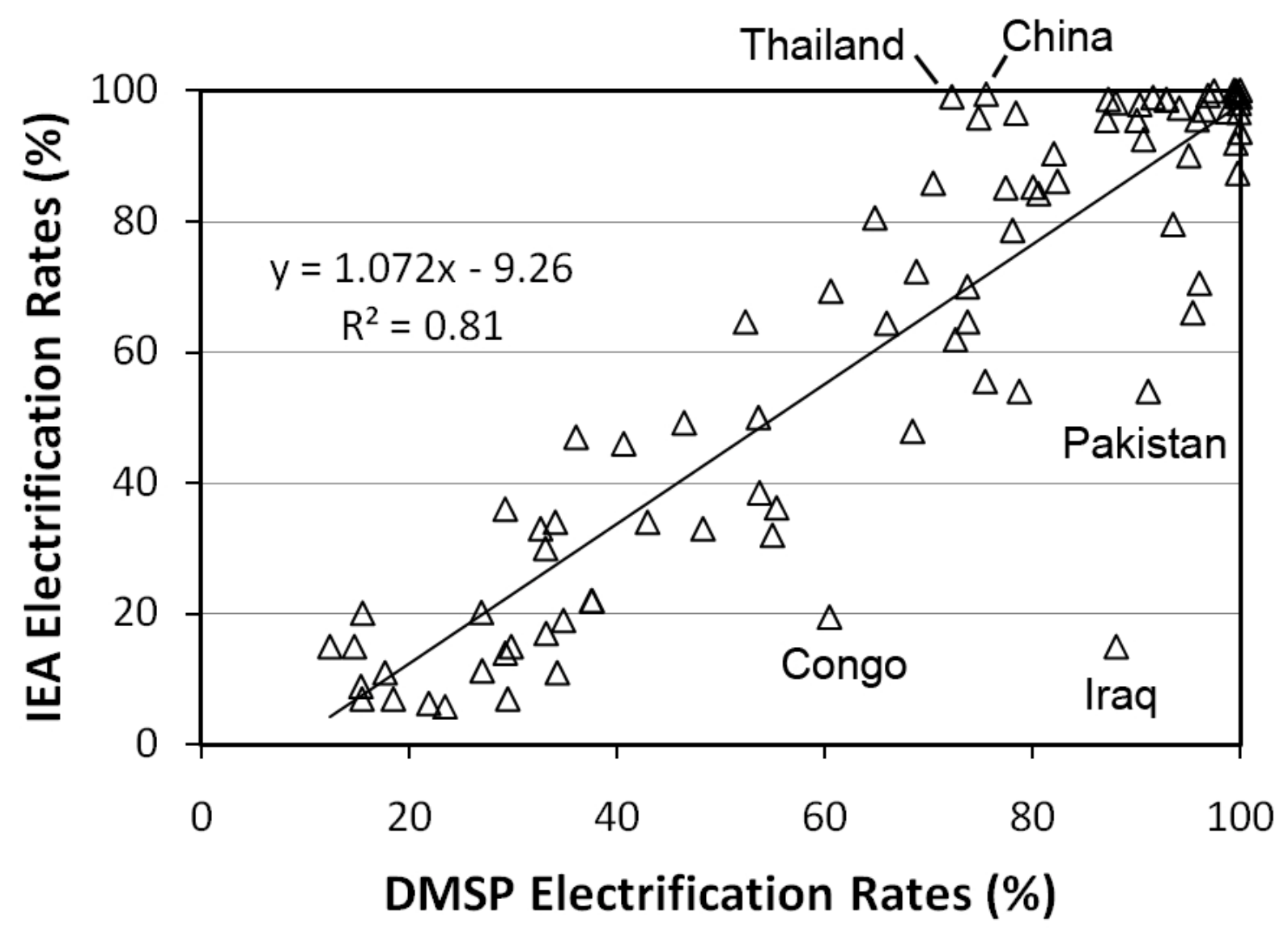

Figure 8. DMSP versus IEA estimates of national electrification rates. The outlier in the bottom right corner is Iraq, and the possible reasons for the discrepancy are discussed in the text. 


\title{
Index Words
}

\author{
Electrification \\ Electrification rates \\ DMSP \\ Nighttime lights \\ Landscan \\ DOE - Department of Energy \\ IEA - International Energy Agency \\ WEO - World Energy Outlook \\ National \\ Subnational \\ Light emitting diode (LED) \\ China \\ India \\ Iraq \\ Russia \\ Nigeria \\ Iran \\ Algeria \\ Libya \\ Thailand \\ Cuba \\ Congo \\ Pakistan \\ Sri Lanka \\ Qatar \\ Indonesia \\ Lesotho \\ Bangladesh \\ Afghanistan \\ Gabon \\ Brazil \\ Philippines \\ Paraguay \\ Mongolia \\ Chile \\ Cameroon
}

